\title{
A 560 yr summer temperature reconstruction for the Western Mediterranean basin based on stable carbon isotopes from Pinus nigra ssp. laricio (Corsica/France)
}

\author{
S. Szymczak ${ }^{1}$, M. M. Joachimski ${ }^{1}$, A. Bräuning ${ }^{2}$, T. Hetzer ${ }^{2,3}$, and J. Kuhlemann ${ }^{4}$ \\ ${ }^{1}$ GeoZentrum Nordbayern, University of Erlangen-Nuremberg, Erlangen-Nuremberg, Germany \\ ${ }^{2}$ Institute of Geography, University of Erlangen-Nuremberg, Erlangen-Nuremberg, Germany \\ ${ }^{3}$ Department of Palynology and Climate Dynamics, Albrecht-von-Haller-Institute for Plant Sciences, \\ Georg-August-University Göttingen, Göttingen, Germany \\ ${ }^{4}$ Eidgenössisches Nuklearsicherheitsinspektorat - ENSI, Brugg, Switzerland
}

Correspondence to: S. Szymczak (sonja.szymczak@geol.uni-erlangen.de)

Received: 6 June 2012 - Published in Clim. Past Discuss.: 12 June 2012

Revised: 4 September 2012 - Accepted: 5 October 2012 - Published: 30 October 2012

\begin{abstract}
The Mediterranean is considered as an area which will be affected strongly by current climate change. However, temperature records for the past centuries which can contribute to a better understanding of future climate changes are still sparse for this region. Carbon isotope chronologies from tree-rings often mirror temperature history but their application as climate proxies is difficult due to the influence of the anthropogenic change in atmospheric $\mathrm{CO}_{2}$ on the carbon isotope fractionation during photosynthetic $\mathrm{CO}_{2}$ uptake. We tested the influence of different correction models accounting for plant response to increased atmospheric $\mathrm{CO}_{2}$ on four annually resolved long-term carbon isotope records (between 400 and $800 \mathrm{yr}$ ) derived from Corsican pine trees (Pinus nigra ssp. laricio) growing at ecologically varying mountain sites on the island of Corsica. The different correction factors have only a minor influence on the main climate signals and resulting temperature reconstructions. Carbon isotope series show strong correlations with summer temperature and precipitation. A summer temperature reconstruction (1448-2007 AD) reveals that the Little Ice Age was characterised by low, but not extremely low temperatures on Corsica. Temperatures have been to modern temperatures at around $1500 \mathrm{AD}$. The reconstruction reveals warm summers during 1480-1520 and 1950-2007 AD and cool summers during 1580-1620 and 1820-1890 AD.
\end{abstract}

\section{Introduction}

Mediterranean ecosystems are among the most sensitive ecosystems to current climate change (IPCC, 2007). Located in the transition zone between the west wind drift and the subtropical high pressure belt, the Mediterranean basin already suffers from severe drought during summer months (Touchan et al., 2008a,b, 2011). The expected strong temperature increase and precipitation decrease will intensify drought stress and lead to a northward extension of dry and arid land (Christensen, 2007; Gao and Giorgi, 2008).

An evaluation of current climate change and the adaptation potential of different ecosystems is only possible with solid knowledge about past climate changes. Most instrumental records are rather short making it impossible to detect long-term changes and to examine the full range of climate variability (Hulme and Jones, 1994). Climate proxies, such as tree rings, corals and ice cores, are important archives to reconstruct climate changes further back in time. Trees are one of the best natural archives of recent and Holocene environmental conditions because they are widespread, sensitive to their environment and provide a continuous record with annual resolution. Tree-ring width chronologies from the Mediterranean have been used to reconstruct temperature (Büntgen et al., 2008; Guiot et al., 1988; Popa and Kern, 2009; Serre-Bachet and Guiot, 1987; Serre-Bachet, 1994), precipitation (Akkemik and Aras, 2005; Akkemik et al., 2005, 2008; D'Arrigo and Cullen, 2001; Griggs et al., 2007;

Published by Copernicus Publications on behalf of the European Geosciences Union. 
Till and Guiot, 1990; Touchan et al., 1999, 2003, 2005a,b; 2007), drought (Chbouki et al., 1995; Nicault et al., 2008), NAO-Index (Glueck and Stockton, 2001) and scPDSI-Index (Brewer et al., 2007; Esper et al., 2007).

Stable carbon isotopes in tree rings contain information about past climate and seem to be less influenced by nonclimatic factors than tree-ring width (e.g. Danis et al., 2006; Gagen et al., 2007; Kress et al., 2010; Young et al., 2011). The carbon isotope ratio of tree-ring cellulose is determined by fractionation processes during photosynthesis which in turn depend on the ratio of the intercellular leaf to atmospheric $\mathrm{CO}_{2}$ concentration (Farquhar et al., 1982) and the $\delta^{13} \mathrm{C}$ value of atmospheric $\mathrm{CO}_{2}$. The rate of photosynthesis strongly depends on climate conditions, so that $\delta^{13} \mathrm{C}$ ratios of tree-ring cellulose often show high correlations with climate parameters and can be used to reconstruct temperature (Edwards et al., 2008; Etien et al., 2008; Gagen et al., 2007; Hilasvuori et al., 2009; Lipp et al., 1991; Masson-Delmotte et al., 2005; Treydte et al., 2009; Young et al., 2010), precipitation (Bale et al., 2011; Sho et al., 2009), water stress (Masson-Delmotte et al., 2005) or drought conditions (Kress et al., 2010). However, in comparison to tree-ring width studies, published long-term isotope records (more than $300 \mathrm{yr}$ ) are relatively rare due to the generally high effort of constructing isotope chronologies.

In this manuscript, we present four annually resolved longterm carbon isotope records (between 400 and $800 \mathrm{yr}$ ) derived from Corsican pine trees (Pinus nigra ssp. laricio) growing at ecologically varying mountain sites on the island of Corsica in the Western Mediterranean. Our objectives are to (i) detect local differences between the isotope records, (ii) evaluate the climate-isotope relationship and (iii) present a summer temperature reconstruction for the Western Mediterranean.

\section{Study site}

Corsica, an island located in the Western Mediterranean basin between $41-43^{\circ} \mathrm{N}$ and $8-10^{\circ} \mathrm{E}$, is characterised by a steep relief with rugged mountain ranges and deep valleys. The main mountain range with several peaks above $2000 \mathrm{~m}$ a.s.l. is composed of Variscan basement dominated by calc-alkaline and alkaline granites (Rossi and Cocherie, 1991). The climate of Corsica is influenced by its location in the Mediterranean area and the mountain topography which results in different local climates. Climate close to the coast is subtropical Mediterranean characterised by dry warm summers (May to September) and temperate wet winters (October to April). Mean annual precipitation along the coast ranges from $105 \mathrm{~mm} \mathrm{a}^{-1}$ to $814 \mathrm{~mm} \mathrm{a}^{-1}$ and mean monthly temperature is around $15^{\circ} \mathrm{C}$ (time period: 19512008; Météo-France, 2010). In general, temperature decreases (approximately $0.57^{\circ} \mathrm{C} / 100 \mathrm{~m}$ ) and precipitation increases (up to $1400 \mathrm{~mm} \mathrm{a}^{-1}$ at $1000 \mathrm{~m}$ a.s.l.) with altitude.
Temperature is strongly determined by altitude, while precipitation shows a more diverse pattern with the northeastern part of the mountains being somewhat drier than the southern and western coastal mountain ranges. The Niolo high valley close to the study site Ballone is one of the driest mountain areas. In the higher mountains, snow is the main precipitation in winter with a continuous snow layer from December to April from $1500 \mathrm{~m}$ a.s.l. upwards.

Corsican pine (Pinus nigra ssp. laricio) is the dominating tree species in the mountains of Corsica and forms a forest belt between 1000 and $1800 \mathrm{~m}$ a.s.l. (Kuhlemann et al., 2009). Several individuals reach ages up to $800 \mathrm{yr}$ or older, which are among the oldest living trees found in the Mediterranean. We sampled Pinus nigra trees at 4 ecologically varying upper tree line sites (Fig. 1). The site Asco ( $1500 \mathrm{~m}$ a.s.l.) is located in the headwaters of an east-west striking valley north of Monte Cinto (2706 m a.s.l.). Trees are growing on a blocky terminal moraine. The site Ballone $(1650 \mathrm{~m}$ a.s.l.) in a secondary valley of the dry Niolo high valley at the southern slopes of Monte Cinto is characterised by a warm and dry local climate with more pronounced drought stress than at Asco. Sampled trees grow on a steep slope with sparse vegetation cover. The upper tree line at site Capannelle (1700 m a.s.l.), located on the southeast exposed slopes of Monte Renoso (2352 m a.s.1.), is dominated by Pinus nigra and Fagus sylvatica (European beech). Since air masses from the east coast can nearly unhampered reach the site and since fog occurrence is common, the local climate can be characterised as relatively cold and wet. The site Asinao (1350 m a.s.1.) is located in the Asinao valley, a northeast-southwest striking valley south of Monte Incudine (2136 m a.s.1.), the highest massif in southern Corsica. Sampled trees grow on a talus slope consisting of granite blocks and thin soils with low water-holding capacity.

\section{Materials and methods}

We cored 5-6 trees per site since isotope values from $P i$ nus nigra measured on individual trees show a comparable high variability and a smaller number of trees seems to be insufficient to represent the environmental conditions at a specific site (Szymczak et al., 2012). Mean ages of sampled trees range from 700 (Asco) to $390 \mathrm{yr}$ (Capannelle; Table 1). After dating and crossdating the tree cores with the program TSAP (Rinn, 2008), one core from each tree was selected for isotope analysis. Tree rings were separated with a scalpel and contemporaneous material from 5-6 trees per site was pooled prior to cellulose extraction. Pooling of several trees reduces the number of samples to be analysed and pooled samples from Pinus nigra correspond well to chronologies based on mean values calculated from analyses of individual trees (Szymczak et al., 2012). Cellulose extraction was shown to be an important prerequisite for the development of isotope series from Pinus nigra (Szymczak 
Table 1. Parameters of the study sites and carbon isotope chronologies. As: Asco, Ba: Ballone, Ca: Capannelle, Ai: Asinao, mean $\delta^{13} \mathrm{C}_{\text {pin }}$ (\% VPDB): mean value of carbon isotope chronology corrected with the pin correction (McCarroll et al., 2009) for the time period 15822007 AD.

\begin{tabular}{ccccccc}
\hline & $\begin{array}{c}\text { altitude } \\
(\mathrm{m} \text { a.s.1. })\end{array}$ & $\begin{array}{c}\text { latitude, } \\
\text { longitude }\end{array}$ & $\begin{array}{c}\text { no. of } \\
\text { trees }\end{array}$ & $\begin{array}{c}\text { time } \\
\text { period }\end{array}$ & $\begin{array}{c}\text { mean tree } \\
\text { age } \\
\text { (in 2012) }\end{array}$ & $\begin{array}{c}\text { mean } \\
\delta^{13} \mathrm{C}_{\text {pin }} \\
(\% \circ \text { VPDB })\end{array}$ \\
\hline $\mathrm{As}$ & 1500 & $42.24^{\circ} \mathrm{N}, 8.56^{\circ} \mathrm{E}$ & 6 & $1185-2008$ & 700 & -20.58 \\
$\mathrm{Ba}$ & 1650 & $42.21^{\circ} \mathrm{N}, 8.54^{\circ} \mathrm{E}$ & 6 & $1404-2008$ & 502 & -21.22 \\
$\mathrm{Ca}$ & 1700 & $42.05^{\circ} \mathrm{N}, 9.09^{\circ} \mathrm{E}$ & 5 & $1582-2010$ & 390 & -21.52 \\
$\mathrm{Ai}$ & 1350 & $41.50^{\circ} \mathrm{N}, 9.12^{\circ} \mathrm{E}$ & 6 & $1448-2009$ & 479 & -21.83 \\
\hline
\end{tabular}

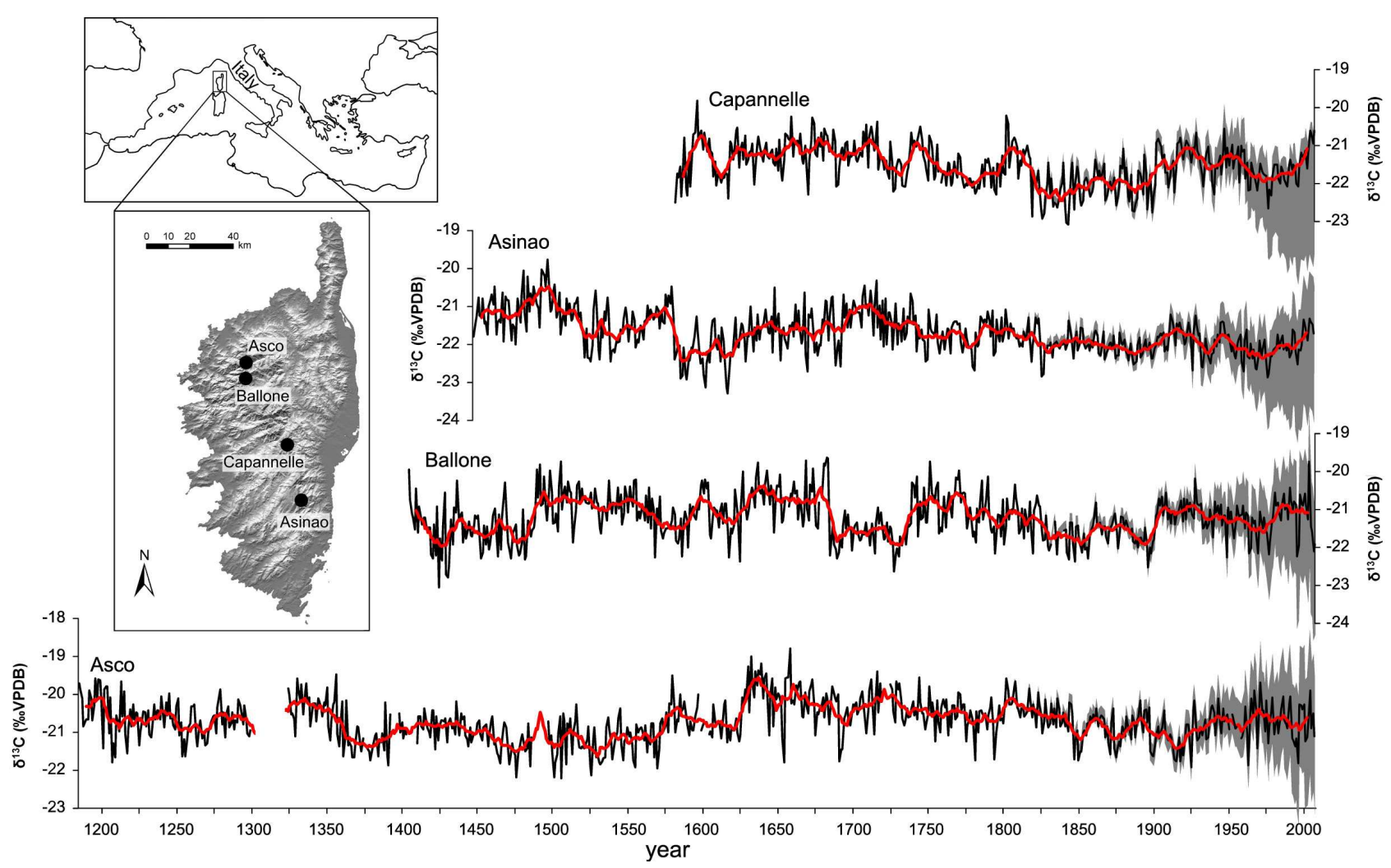

Fig. 1. Annually resolved carbon isotope chronologies for four mountain sites on Corsica. Isotope chronologies were corrected for changes in atmospheric $\mathrm{CO}_{2}$ concentration and for plant physiological responses with the pin-correction (McCarroll et al., 2009). Grey shaded areas illustrate the range of isotope values corrected with different correction factors. Lower limit: raw uncorrected values, upper limit: corrected with the correction factor from Feng and Epstein (1995). Studies locations are marked on the map (left panel), small map shows the location of Corsica in the Mediterranean basin.

et al., 2011). The cellulose extraction followed the standard method of Kürschner and Popik (1962) and included delignification with acidified sodium chlorite solution (7\%) and alkaline hydrolysis with sodium hydroxide (17\%). Following Boettger et al. (2007), a $17 \%$ instead of a $5 \%$ sodium hydroxide solution was used to extract $\alpha$-cellulose.

For carbon isotope analyses, subsamples from each year were weighed into tin capsules $(0.4-0.7 \mathrm{mg})$. Carbon isotope ratios were determined using a CE 1110 elemental analyser coupled online to a ThermoFisher Delta Plus mass spectrometer. Isotopic compositions are reported in permil using the conventional $\delta$ notation relative to VPDBstandard (Vienna Pee Dee Belemnite). Reproducibility (1 std.dev) based on replicate analyses of 142 IAEA-CH3 and 178 USGS40 standards was $< \pm 0.1 \%$.

Correlations between carbon isotopes and mean monthly precipitation and temperature were calculated with the program DENDROCLIM 2002 (Biondi and Waikul, 2004). Climate records from the island of Corsica are rather short and cover only $50 \mathrm{yr}$ for coastal and only around $30 \mathrm{yr}$ for 
mountain stations. Since climate between coastal and mountain stations may be quite different we used a climate data set for Italy provided by the Tyndall Centre for Climate Change Research (Mitchell et al., 2002) that gives average temperature and precipitation (1901-2000) based on all Italian climate stations. The comparison of the Italian data set with Corsican climate records reveals that mean annual precipitation and annual temperature in Italy and Corsican mountain stations are more comparable than between coastal and mountain stations on Corsica. Correlations of tree ring carbon isotope records with temperature and precipitation were calculated only for the time period 1951-2000 because the number of climate stations covering the early $50 \mathrm{yr}$ is considerably lower. Correlations were calculated over an 18months period from previous year May to October of the current year, thus including 2 vegetation periods (May-October) and one vegetation break.

The application of carbon isotope chronologies as reliable climate proxy is hampered since the concentration and isotope composition of atmospheric $\mathrm{CO}_{2}$ was not constant over time. The extensive burning of fossil fuels since the beginning of industrialisation added isotopically light $\mathrm{CO}_{2}$ to the atmosphere resulting in an increase of the atmospheric $\mathrm{CO}_{2}$ concentration from $280 \mathrm{ppm}$ (parts per million) in preindustrial time to $379 \mathrm{ppm}$ in 2005 (IPCC, 2007). Changes in $\delta^{13} \mathrm{C}_{\mathrm{atm}}$ are recorded by a remarkable downward trend in $\delta^{13} \mathrm{C}$ of tree-ring cellulose over the last approximately $150 \mathrm{yr}$. The raw $\delta^{13} \mathrm{C}$ values of tree-ring cellulose are routinely corrected to a pre-industrial atmospheric $\delta^{13} \mathrm{C}$ base value of $-6.4 \%$ by adding published annual values for the ${ }^{13} \mathrm{C}$ decrease in atmospheric $\mathrm{CO}_{2}$, as demonstrated by McCarroll and Loader (2004). A negative trend often remains after correcting for changes in atmospheric $\mathrm{CO}_{2}$ (Treydte et al., 2001; Waterhouse et al., 2004; Gagen et al., 2007; Loader et al., 2007), which is attributed to plants ability to adapt their metabolism to higher atmospheric $\mathrm{CO}_{2}$ levels. Feng and Epstein (1995) and Kürschner (1996) provided correction factors for this plant physiological response. The correction factors were estimated as $0.02 \% \circ \mathrm{ppm}^{-1} \mathrm{CO}_{2}$ (Feng and Epstein, 1995) and $0.0073 \% \mathrm{ppm}^{-1} \mathrm{CO}_{2}$, respectively, (Kürschner, 1996) and represent the upper and lower range of published potential discrimination values (Treydte et al., 2009). McCarroll et al. (2009) developed an alternative correction approach, the so-called "pin-correction", which calculates specific values for each individual tree by removing the low-frequency pattern from the $\delta^{13} \mathrm{C}$ record using nonlinear loess regression. The choice of the appropriate correction model is particularly critical for climate reconstructions because climate data are in most cases only available for the last 50 to $100 \mathrm{yr}$. Thus, the years most affected by the anthropogenic increase in atmospheric $p \mathrm{CO}_{2}$ are used for calibration and verification of the climate-isotope relationship (McCarroll et al., 2009; Treydte et al., 2009). To test the influence of the correction model on the climate-isotope relationship, we calculated correlations for carbon isotope chronologies corrected for changes in $\delta^{13} \mathrm{C}$ of atmospheric $\mathrm{CO}_{2}$ and using the discrimination factors given by (i) Kürschner (1996) $\left(C_{\mathrm{Kü}}\right)$, (ii) Feng and Epstein $(1995)\left(C_{\mathrm{FE}}\right)$, and (iii) corrected with the "pin-correction" $\left(C_{\text {pin }}\right.$; McCarroll et al., 2009).

Strong correlations with summer temperature underline the potential of the isotope chronologies for climate reconstructions. To test the influence of the different correction factors on the resulting reconstruction, we compared two reconstructions, one derived from the $C_{\mathrm{FE}}$-chronology of only one site (Asinao), the other derived from the $C_{\text {pin }}$ mean chronology of two sites (Asinao and Ballone). The climate reconstructions are based on a linear regression model calculated with the software R (www.r-project.org). We used a split calibration-verification scheme and standard statistical parameters including the reduction of error (RE), coefficient of efficiency (CE), sign test (ST) and Pearson's correlation coefficient $(r)$ to test the reliability of the reconstructions (Cook and Kairiukstis, 1990). The climate data set was split in two equal time periods, one was used for calibration, the other for verification and vice versa. No significance level is defined for RE- and CE-values, however, any positive value indicates that there is some useful information in the reconstruction (Cook and Kairiukstis, 1990; Fritts, 1976).

\section{Results}

\subsection{Carbon isotope chronologies}

The study sites are located at different altitudes ranging from $1350 \mathrm{~m}$ a.s.l. (site Asinao) to $1700 \mathrm{~m}$ a.s.l. (site Capannelle) (Table 1). The age structure is also very diverse with the oldest trees growing at the northern sites. The risk of juvenile timbers being included in the pooled records can be excluded since we did not include the oldest $50 \mathrm{yr}$ of each tree in the pooled samples. A dependency of the carbon isotope values on tree age or altitude was not observed. Carbon isotope chronologies from the northern study sites show generally less negative values than chronologies from the southern sites (Fig. 1, Table 1).

The raw values of all sites are characterised by a strong nonrecurring downward trend during the most recent years making a correction procedure necessary. The downward trend even remains after corrections for changing isotopic composition in the atmosphere, indicating that a correction for plant physiological responses is needed. The strength of the correlations between the sites depends on the used correction. Correlations are in general stronger for $C_{\mathrm{FE}^{-}}$and $C_{\mathrm{pin}}$-chronologies than for $C_{\mathrm{Kü}}$-chronologies (Table 2). Asco shows the weakest correlations with the other sites. Ballone is strongly correlated with Asco as well as the southern sites. The strongest correlations are observed between both southern sites (Asinao-Capannelle). Although the correlations between the different sites are relatively low, high Gleichläufigkeits values (60\% for Asco-Capannelle and $69 \%$ 

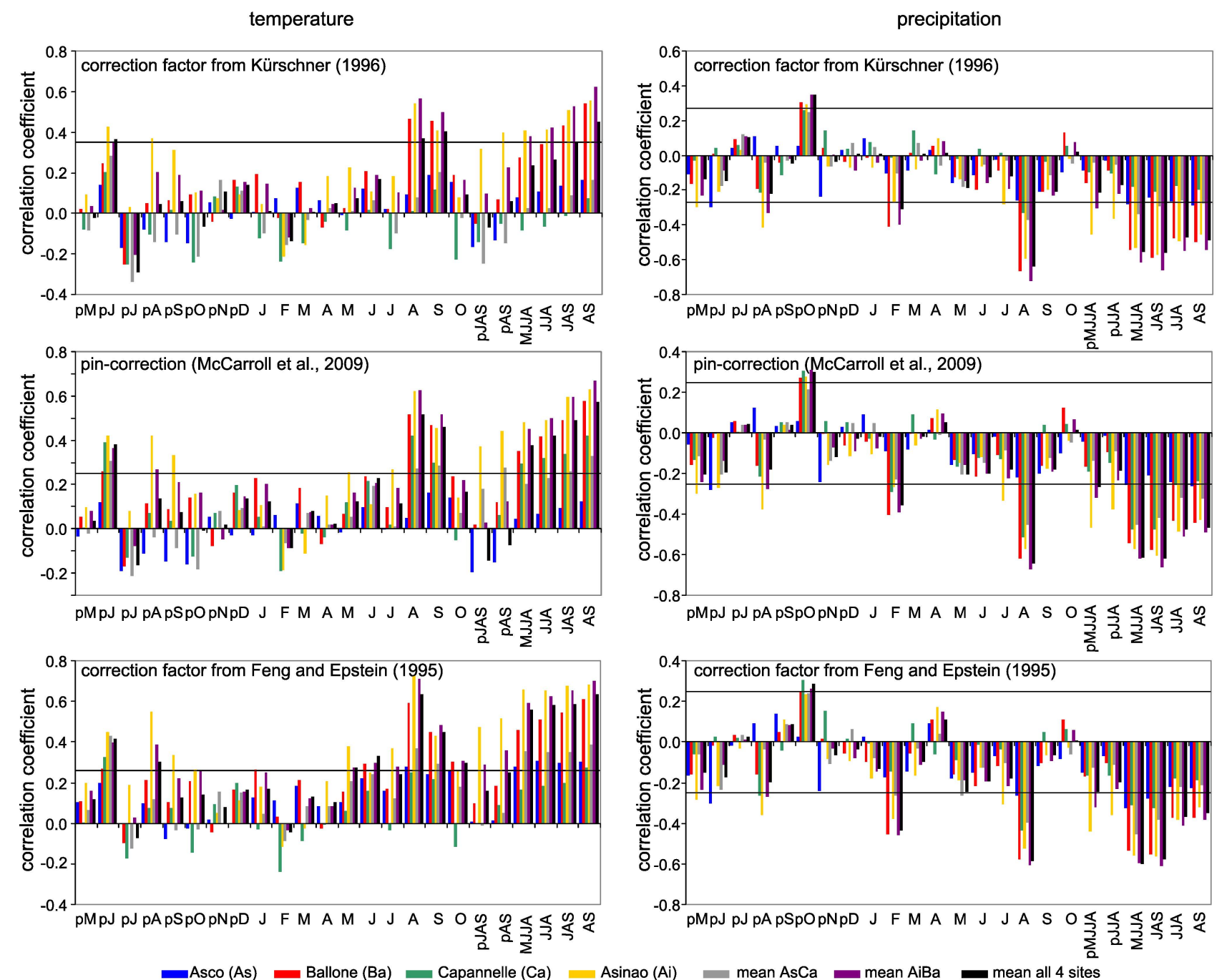

Fig. 2. Pearson correlation coefficients for differently corrected carbon isotope chronologies and mean monthly temperature (left panels) and mean precipitation (right panels) for the time period 1951-2000 plotted for an 18-months period from the previous May (pM) to October of the current year. The vegetation period lasts from May to October. Black horizontal lines represent the significance level $(p<0.05)$.

for Asinao-Ballone) indicate a common driving force on carbon isotope discrimination (Table 3). An EPS value of 0.71 for the pre-industrial period (1582-1844 AD) further underlines the similarities among the different sites.

\subsection{Climate isotope relationship}

Carbon isotope chronologies show strong positive correlations with temperature during the vegetation period, namely in August and September (Fig. 2). The strongest correlation is 0.73 (Asinao $C_{\mathrm{FE}}$ with August temperature). Correlations are in general stronger for the mean of several months from the vegetation period, especially for July/August/September (JAS) and August/September (AS). The correlations are stronger for $C_{\mathrm{FE}^{-}}$and $C_{\mathrm{pin}}$ - than for $C_{\mathrm{Kü}}$-chronologies. The sites Ballone and Asinao are more sensitive to summer temperature than Asco and Capannelle as indicated by stronger and significant correlations. The correlations are improved if a mean chronology for the sites Asinao and Ballone is applied. Asco show the weakest and mainly non-significant correlations.

In contrast to the temperature-isotope relationship, correlations with precipitation are less influenced by the correction factors (Fig. 2). All sites, except Asco, show strong negative correlations with August and June/July/August (JJA) precipitation with the strongest correlations observed for Asinao and Ballone. The strongest correlation is -0.67 (mean AsinaoBallone $C_{\text {pin }}$ with August precipitation). A weaker but significant correlation (Asinao, Ballone and mean of all 4 sites) occurs with February precipitation. Correlations with precipitation are of comparable strength than correlations with temperature. 
Table 2. Pearsons correlation coefficients between chronologies corrected with correction factors from Kürschner $\left(1996 ; C_{\mathrm{Kü}}\right)$ and Feng and Epstein $\left(1995 ; C_{\mathrm{FE}}\right)$ as well as the pin-correction (McCarroll et al., 2009; $\left.C_{\text {pin }}\right)$. Correlations are calculated over the common time period 1582-2007 AD.

\begin{tabular}{lccc}
\hline$C_{\text {Kü }}$ & Ballone & Capannelle & Asinao \\
\hline Asco & 0.33 & 0.25 & 0.29 \\
Ballone & & 0.40 & 0.28 \\
Capannelle & & & 0.44 \\
\hline$C_{\text {pin }}$ & Ballone & Capannelle & Asinao \\
\hline Asco & 0.35 & 0.34 & 0.38 \\
Ballone & & 0.46 & 0.43 \\
Capannelle & & & 0.47 \\
\hline$C_{\text {FE }}$ & Ballone & Capannelle & Asinao \\
\hline Asco & 0.49 & 0.34 & 0.44 \\
Ballone & & 0.48 & 0.43 \\
Capannelle & & & 0.47 \\
\hline
\end{tabular}

In general, Asco and Capannelle are less sensitive to climate parameters than Asinao and Ballone, as indicated by weaker correlations. The strongest correlation from Asco is with MJJA precipitation $(r=-0.33)$ and from Capannelle with August precipitation $(r=-0.52)$. Instead, Ballone and Asinao show strong correlations with both parameters during the vegetation period (strongest correlation at Ballone: -0.66 with August precipitation, strongest correlation at Asinao: 0.73 with August temperature).

A comparable pattern is reflected by the mean carbon isotope chronology of all 4 sites (Fig. 2). Strong correlations occur with both, August temperature and precipitation, but also with temperature and precipitation during several months of the vegetation period. Temperature is more important during the months JAS and AS while precipitation is more important during the months MJJA and JJA. The correlations with temperature are remarkably stronger for the $C_{\mathrm{FE}}$-chronology while the correlations with precipitation are similar among the different correction models. The strong correlations of the mean chronology indicate that all sites are influenced by the same driving force which underlines the representativeness of the isotope chronologies for Corsica. However, the correlations are even stronger when considering the mean of the two most sensitive sites, Asinao and Ballone (Fig. 2).

\subsection{Temperature reconstruction}

The strong correlations with August-September temperature are suitable for a summer temperature reconstruction. In order to test the influence of the correction factors on the resulting reconstruction, we developed two reconstructions: one derived from the Asinao chronology $\left(C_{\mathrm{FE}}\right)$ and the other one from the mean chronology of Asinao-Ballone $\left(C_{\text {pin }}\right)$. The
Table 3. Gleichläufigkeits-values (in \%) between the chronologies from the different sites.

\begin{tabular}{lccc}
\hline & Ballone & Capannelle & Asinao \\
\hline Asco & 62 & 60 & 63 \\
Ballone & & 64 & 69 \\
Capannelle & & & 61 \\
\hline
\end{tabular}

reconstructions are based on linear regression and verified with a split verification-calibration scheme, i.e. the climate data is divided in two equal time periods of $25 \mathrm{yr}$ and the temperature reconstructions derived for the 3 different calibration periods (full period for calibration), P1 (calibration period: 1951-1975) and P2 (calibration period: 1976-2000) are compared. High RE- and CE-values and high synchronicity between the 3 temperature reconstructions underline the validity of the reconstruction from the $C_{\mathrm{FE}}$-chronology (Fig. 3). In contrast, the reconstruction based on the $C_{\text {pin }}$-chronolgy seems to be more influenced by the time period used for calibration. The low frequency signal is preserved very well in both reconstructions while the high frequency variability is reduced in single years, i.e. 1972 or 1996 AD. This can be explained by the fact that temperature is not the only parameter influencing carbon isotope discrimination and that the reconstruction can only explain $48 \%$ of the variability.

The statistical parameters indicate the usefulness of both reconstructions, however, the reconstruction from the $C_{\mathrm{FE}^{-}}$ chronology seems to be more reliable. The comparison of both reconstructions over the time period 1448-2007 AD (Fig. 4) indicates high similarities, although the reconstructed temperatures are different in some periods, namely from 1480-1580 $\mathrm{AD}$ (lower temperatures from Asinao $C_{\mathrm{FE}}$ ) and from 1940-2007 (higher temperatures from Asinao $C_{\mathrm{FE}}$ ). Temperatures reconstructed with the $C_{\text {pin }}$-chronology are in general slightly higher.

General features of the reconstructions are high temperatures at the beginning of the reconstructed period with a local maximum at around $1500 \mathrm{AD}$. Temperatures decreased, with a short interruption at around $1575 \mathrm{AD}$, to rather low temperatures in the period around 1580-1620 AD. Afterwards, temperature increased again to local maxima at around 1640-1650 AD and 1700-1720 AD, followed by a longer period with low temperatures with little high frequency variability at $1720-1820 \mathrm{AD}$. The period $1820-1900 \mathrm{AD}$ is characterised by low temperatures. The current temperature increase commenced at approximately $1900 \mathrm{AD}$, interrupted by two phases of lower temperatures (1937 and $1970 \mathrm{AD})$. The strongest temperature increase is observed from $1980 \mathrm{AD}$ onwards. 

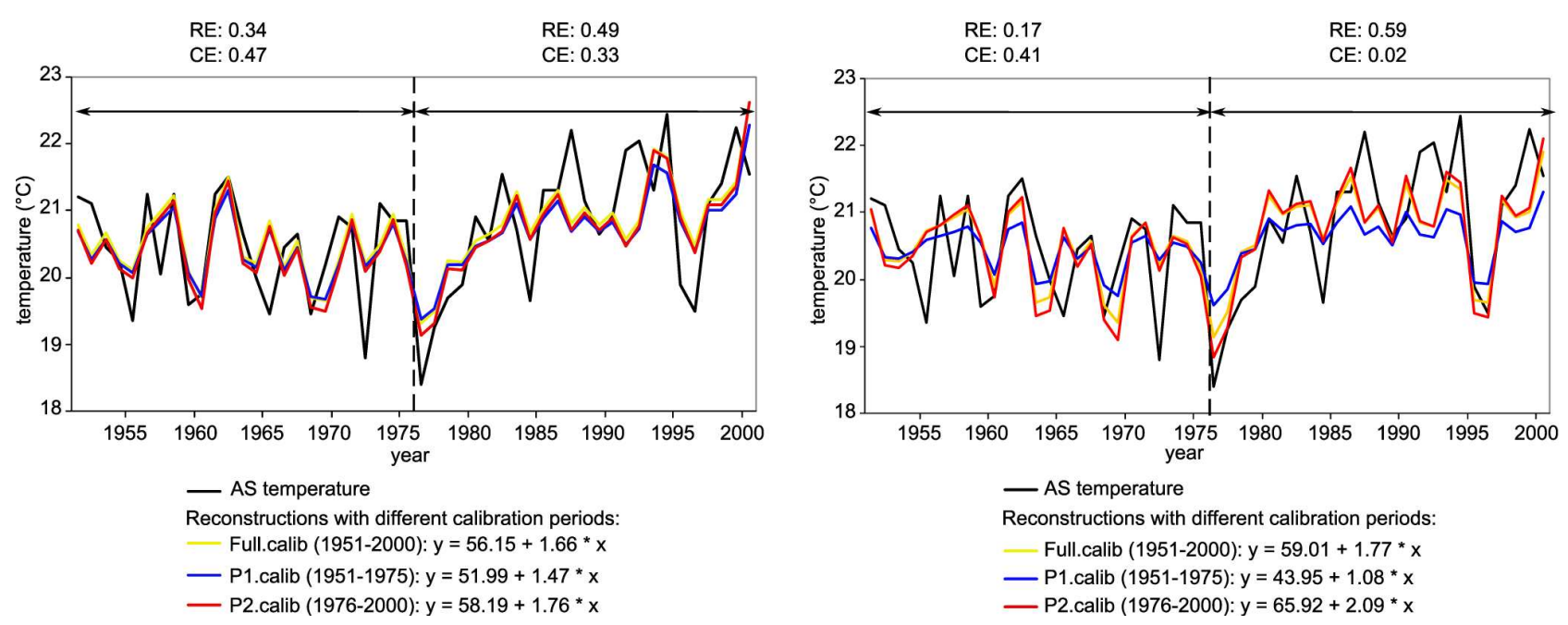

Fig. 3. Split calibration-verification scheme of the two August/September temperature reconstructions: reconstruction based on FE-corrected Asinao chronology (left panel), reconstruction based on pin-corrected mean chronology Asinao-Ballone (right panel). The climate data set is devided in two equal time periods P1 and P2 for calibration and verification, respectively. RE: reduction of error; CE: coefficient of efficiency.

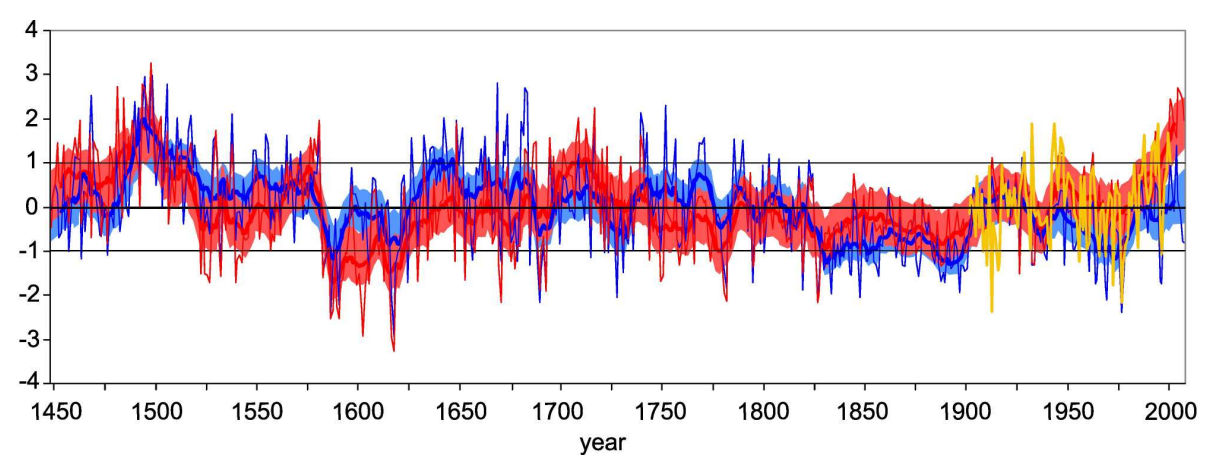

Fig. 4. Reconstructed August/September temperature derived from the FE-corrected carbon isotope chronology of site Asinao (red) and the pin-corrected mean carbon isotope chronology of sites Asinao-Ballone (blue) presented as deviation from the mean 1951-2000 AD. The smoothed lines represent an 11-yr running mean, the red and blue shaded areas around the chronologies illustrate the calibration $( \pm 1$ standard deviation). Orange line shows the instrumental record, horizontal lines indicate the mean and \pm 1 standard deviation.

\section{Discussion and conclusions}

\subsection{Carbon isotopes in tree-ring cellulose as climate proxy}

Increasing atmospheric $\mathrm{CO}_{2}$ concentration affects leaf internal discrimination against ${ }^{13} \mathrm{C}$ and must be considered when interpreting $\delta^{13} \mathrm{C}$ values of tree-ring cellulose. As noted by several authors, a correction for the increase in atmospheric $p \mathrm{CO}_{2}$ seems to be insufficient (Feng and Epstein, 1995; Gagen et al., 2007; Treydte et al., 2001, 2009; McCarroll et al., 2009) and should be combined with a correction for plant physiological responses to higher $\mathrm{CO}_{2}$ levels. However, this correction is not well constrained. Published discrimination values were mainly derived from short-term experiments because the growth response of mature trees is difficult to assess due to their long life cycle. Thus, it is questionable whether these correction factors can easily be transferred to a longterm response of living trees. As a result from metabolic acclimation and age-related stand dynamics, $\mathrm{CO}_{2}$ effects decline over time (Hättenschwiler et al., 1997). Elevated $\mathrm{CO}_{2}$ may stimulate tree growth, however, the effect is species dependent (Dawes et al., 2011) and tree growth seems to be carbon-saturated already under present environmental conditions (Körner, 2006). Using wood from different species of old grown trees (among these several Pinus-species) in dry mountain environments, Feng and Epstein (1995) performed the only existing study that investigated long-term isotopic trends for the calculation of a discrimination factor. Since their trees were growing in rather similar environments than the Corsican pine trees investigated in this study, the application of the Feng and Epstein (1995) correction factor seems to be suitable in our case. However, it should be kept in mind that there is a risk of selecting inappropriate 
carbon isotope correction factors by "tuning" them to the climate factor desired to be reconstructed, in this case summer temperature which has shown an increasing trend during the past decades. Indeed, the reconstructed climate signal is influenced by the correction factors applied, although in our study only the strength of the correlation is affected. The main signal remains constant, i.e. strongest correlations are always observed in the same months independent of the applied correction factor.

The $C_{\mathrm{FE}}$ correction is at the upper limit of published discrimination values and the strong physiological response to increased $\mathrm{CO}_{2}$ contradicts the findings of Dawes et al. (2011) reporting that Pinus uncinata in the Alps is less sensitive to increased $\mathrm{CO}_{2}$ than Larix decidua. This different response can be attributed to differences in temperature sensitivity. At the upper tree line in the Alps and on Corsica, temperature is the most important parameter limiting tree growth, although in a different way. In the Alps, temperature determines the length of the vegetation period. Rising temperatures therefore prolong the vegetation period and stimulate tree growth. On Corsica, high temperatures limit tree growth as consequence of pronounced drought stress during the vegetation period. Due to low summer precipitation, trees are forced to reduce their photosynthetic activity in order to reduce water loss. Lower temperatures in combination with higher precipitation are therefore stimulating tree growth on Corsica. These findings underline the importance of site and species-specific correction factors for the physiological response to increased $p \mathrm{CO}_{2}$.

Besides the Feng and Epstein (1995) correction, the pincorrection (McCarroll et al., 2009) was applied to our data series in order to confirm the validity of the summer temperature reconstruction and invalidate the risk of tuning the correction factor to the climate factor desired to be reconstructed. Advantages of the pin-correction are the independency of the correction procedure from climate data, the calculation of an individual response for each tree and that only those changes in $\delta^{13} \mathrm{C}$ are removed which can be explained by a physiological response (McCarroll et al., 2009). However, McCarroll et al. (2009) stated that "the correction is unique to each tree" and that "the correction (indeed any corrections) should be calculated for each tree individually, so that the mean between-tree correlations and expressed population signal can be calculated." Neither EPS nor mean between-tree correlations can be calculated from pooled series without analysis of individual trees. Nevertheless, the pin-correction has been applied to pooled chronologies (e.g. Young et al., 2012).

Szymczak et al. (2012) developed carbon isotope chronologies of 5 individual trees from one site as well as a pooled chronology consisting of the same 5 trees for a common time period (1961-2007 AD). We applied the pincorrection to this data set and compared the calculated mean from the individually pin corrected series with the pin corrected pooled series. The results indicate that the correction

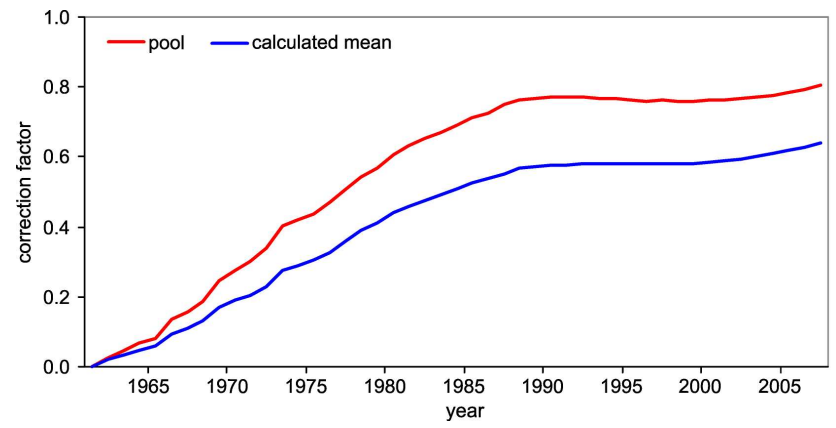

Fig. 5. Annual pin correction values added to atmospheric corrected carbon isotope series calculated for a pooled pin corrected chronology and a mean chronology calculated from five individually pin corrected series from site Capannelle (1961-2227 AD). Both chronologies consists of the same five trees.

factors are different although the chronologies are corrected with respect to a common time period (Fig. 5). The application of the pin-correction for pooled carbon isotope series from Pinus nigra on Corsica should therefore be treated with caution.

Both correction procedures (applying published discrimination factors and the individually calculated pin-correction) therefore have limitations when correcting pooled carbon isotope chronologies for reconstruction purposes. By comparing the two different temperature reconstructions, we observe high similarities confirming a strong common signal independent from the correction procedure underlining the validity of the reconstructions (Fig. 4).

\subsection{Climate signals in carbon isotope series}

The highest similarities in the correlations between the corrected carbon isotope ratios and climate parameters are observed between Ballone in the northern part and Asinao in the southern part of Corsica. This suggests that there is no latitudinal dependency in the factors influencing carbon isotope discrimination. Instead, local site conditions are more important. Ballone and Asinao are the driest and most extreme study sites where trees grow either on a steep slope or on a blocky talus slope, both sites characterised by low water holding capacity. Trees at Capannelle and Asco grow at less steep slopes composed of fine-grained material and a higher water holding capacity. In addition, site Capannelle is wetter than the other sites since it is not sheltered against clouds moving inland from the coast. Although the drier sites Ballone and Asinao react more sensitive to changes in temperature and precipitation, all sites show similar correlations with climate factors, with significant correlations occurring in the same months. This finding underlines the importance of a common driving force for isotope discrimination at all sites. Strong correlations with both, summer temperature and precipitation, reveal that the combination of both factors is 


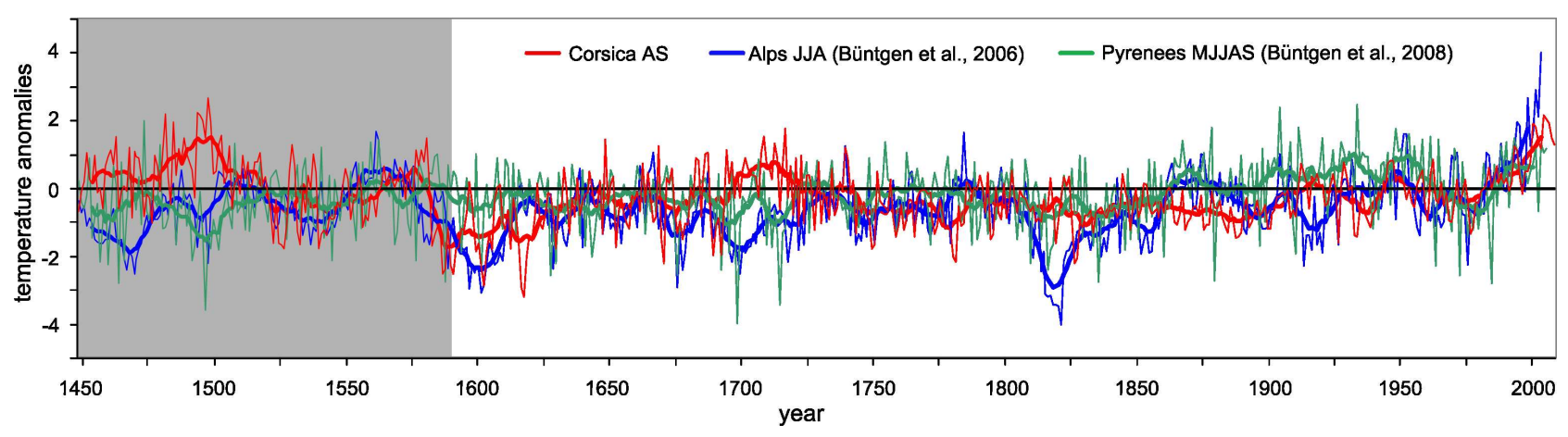

Fig. 6. Comparison of the August/September temperature reconstruction from Corsica (derived from Asinao $C_{\mathrm{FE}}$-chronology) with summer temperature reconstructions from the Alps (Búntgen et al., 2006) and Pyrenees (Büntgen et al, 2008) (data available from NOAA Paleoclimatology Program: www.ndcc.gov/paleo/recons.html). Temperatures are expressed as anomalies. Reconstructions for the Alps and the Pyrenees are based on maximum latewood density series from Larix decidua and Pinus uncinata. Grey shaded area marks the part of the Corsican reconstruction where the pooled isotope chronology is based on less than 6 trees.

important for the carbon isotope fractionation in tree-ring cellulose of Pinus nigra.

\subsection{Summer temperature reconstruction}

The presented $560 \mathrm{yr}$ long temperature reconstruction for Corsica documents rapid temperature changes with temperatures remarkably lower but also at a comparable high level as modern temperatures (Fig. 4). The longevity of Pinus nigra ssp. laricio proves the adaptation potential of this tree species to different climates. Pinus nigra is a pioneer tree species with a wide ecological amplitude and perfectly adapted to Mediterranean mountain areas because it can withstand strong insolation, hot summers and drought stress during the vegetation period (Richardson, 1998). However, Pinus nigra needs sunny conditions and suffers from competition with Fagus sylvatica and Abies alba in the mountains (Kuhlemann et al., 2009) and with Pinus pinaster in lowland areas. Currently, Pinus nigra is the dominant tree species of Corsican forests but Pinus pinaster is better adapted to forest fires (Pimont et al., 2011). In a future drier climate with increasing fire frequency, Pinus nigra populations may therefore decrease in Corsican forests.

The comparison of the summer temperature reconstruction for Corsica with temperature reconstructions for the Alps (Büntgen et al., 2006) and Pyrenees (Büntgen et al., 2008) reveals that all reconstructions report a strong temperature increase since approximately 1980 AD (Fig. 6). The Corsican temperature reconstruction shows higher similarities with the Alps than with the Pyrenees, with a cold phase (1580$1620 \mathrm{AD}$ ) evident in both records. However, the Corsica reconstruction does not mirror the alpine temperature minimum around $1820 \mathrm{AD}$. At around $1500 \mathrm{AD}$ and $1710 \mathrm{AD}$, both reconstructions show diverging behaviour with high temperatures observed on Corsica and low temperatures in the Alps. Little similarities are found between the temperature reconstructions for Corsica and the Pyrenees, especially in the oldest part (1448-1720 AD). Both reconstructions run in the opposite direction at around 1500 AD. During 17202007 AD, the similarities between both reconstructed temperature records are higher, especially concerning the temperature increase after $1980 \mathrm{AD}$. The warm period on Corsica during 1690-1740 AD is neither reflected by the Alps nor the Pyrenees, but is observed in a temperature reconstruction for the Carpathians (Popa and Kern, 2009). Popa and Kern (2009) suggested that the Carpathians were decoupled from the large scale cooling during the Maunder minimum, a period characterised by cool wet summers in Europe. On a hemispheric scale, the Maunder minimum was not a pronounced cold period (Landsberg, 1980) and possibly the climate of the Mediterranean was decoupled from the European climate north of the Alps. This hypothesis is supported by Camuffo (1987) who reported that freezing of the Venetian lagoon was very uncommon during the Maunder minimum.

Large volcanic eruptions are one of the major natural drivers for climate cooling by adding large amounts of aerosols and ash particles to the atmosphere (Briffa et al., 1998; D'Arrigo and Jacoby, 1999). Thus, volcanic eruptions are often followed by cool summers. Periods with enhanced volcanic activity occurred approximately 1560 $1700 \mathrm{AD}, 1800-1920 \mathrm{AD}$ and around $1900 \mathrm{AD}$, as reflected by low values in the Corsican temperature reconstruction. A comparison with the freezing events of the Venetian lagoon (Camuffo, 1987) reveals that most of these years were characterised by low temperatures in Corsica, however, freezing occurred also in some years with high temperatures. This might be explained by the fact that the reconstruction reflects summer temperatures while the freezing occurred during winter.

In comparison to other temperature reconstructions it is notable that the last cold phase of the Little Ice Age (LIA) around $1850 \mathrm{AD}$ is not prominent in the Corsican temperature reconstruction. The LIA on Corsica is characterised by 
relatively low, but not extremely low temperatures. This is attributed to the location of the studied sites. While temperature reconstructions for the Alps, the Pyrenees or the Carpathian Mountains were compiled from trees growing in large mountain ranges surrounded by extensive landmasses, the mountain range of Corsica is relatively small and surrounded by the Mediterranean Sea. Thus, the more maritime climate will be characterised by dampened temperature extremes. As a consequence, the climate of Corsica during the LIA was milder than in other mountain ranges characterised by a more continental climate. Another factor for less pronounced cooling on Corsica might be the small extension of glaciers on Corsica, although knowledge about the glaciation history of Corsica is still incomplete (Conchon, 1978, 1986; Kuhlemann et al., 2005; Reille et al., 1997). Large landmasses facilitate growth of extensive icefields with glaciers further accelerating cooling of mountain areas. Climate during the LIA was characterised by dry-cold winters in the Alps and cool-wet winters in the Mediterranean (Luterbacher et al., 2004; Pauling et al., 2006). Higher precipitation amounts allow a better refill of water reservoirs and hence less pronounced drought stress during the vegetation period with a positive influence on tree growth. Cool wet summers during the LIA were favourable for Pinus nigra on Corsica and can explain the lower sensitivity to colder temperatures compared to trees growing in the Alps or the Pyrenees. Discrepancies between the reconstructions from the Alps, Pyrenees and Corsica can further result from the studied proxies. Maximum latewood density used for the temperature reconstructions in the Alps and Pyrenees, is highly dependent on temperature while the carbon isotope series from Pinus nigra are influenced by both temperature and precipitation. Carbon isotope chronologies can therefore carry a mixed climate signal with, for example, humiditiy being more important than temperature in specific years.

The presented temperature reconstruction indicates that Corsican climate was different from the climate history in other European mountain regions, underlining the uniqueness of this mountainous Mediterranean island. However, large-scale changes, as low temperatures during the LIA and recent warming are recorded, indicating the connection to large-scale circulation dynamics. The climate regime of the Mediterranean is rather complex and is strongly influenced by the position of the polar front and the intertropical convergence zone (ITCZ). A southerly position of the polar front during the Last Glacial Maximum allowed Arctic air masses to invade into the western Mediterranean more frequently and persistently than today (Kuhlemann et al., 2008), while a northward movement of the intertropical convergence zone entrains more subtropical air masses to enter the Mediterranean basin. During the LIA, the position of the ITCZ has been further south in the Pacific region, whereas a northward shift can be observed during recent time (Sachs et al., 2009). These large-scale circulation dynamics determine climate evolution on Corsica. A further northward shift of the
ITCZ may have a serious impact on tree growth in Corsican mountains with a prolongation of drought periods during summer months. Palaeoclimate reconstructions based on tree-ring parameters can help to better understand the adaptation potential of different tree species to past and predicted future climate changes. The spatial and temporal resolution of existing future climate scenarios is still limited due to sparse coverage with longer instrumental climate data or climate proxies in the Mediterranean. Thus, this first multicentury temperature reconstruction from Corsica contributes to the understanding of past climate changes on a local scale.

Acknowledgements. The authors thank the German Science Foundation for financial support (project JO 219/11-1). Daniele Lutz and Eva-Maria Harth are thanked for support during cellulose extraction and isotope analyses.

Edited by: J. Guiot

\section{References}

Akkemik, Ü. and Aras, A.: Reconstruction (1689-1994 AD) of April-August precipitation in the southern part of central Turkey, Int. J. Climatol., 25, 537-548, 2005.

Akkemik, Ü., Dagdeviren, N., and Aras, A.: A preliminary reconstruction (A.D. 1635-2000) of spring precipitation using oak tree rings in the western Black Sea region of Turkey, Int. J. Biometeorol., 49, 297-302, 2005.

Akkemik, Ü., D’Arrigo, R., Cherubini, P., Köse, N., and Jacoby, G. C.: Tree-ring reconstructions of precipitation and streamflow for north-western Turkey, Int. J. Climatol., 28, 173-183, 2008.

Bale, R. J., Robertson, I., Salzer, M. W., Loader, N. J., Leavitt, S. W., Gagen, M., Harlan, T. P., and McCarroll, D.: An annually resolved bristlecone pine carbon isotope chronology for the last millenium, Quatern. Res., 76, 22-29, 2011.

Biondi, F. and Waikul, K.: DENDROCLIM2002: A C++ program for statistical calibration of climate signals in tree-ring chronologies, Comput. Geosci., 30, 303-311, 2004.

Boettger, T., Haupt, M., Knöller, K., Weise, S. M., Waterhouse, J. S., Rinne, K. T., Loader, N. J., Sonninen, E., Jungner, H., MassonDelmotte, V., Stievenard, M., Guillemin, M.-T., Pierre, M., Pazdur, A., Leuenberger, M., Filot, M., Saurer, M., Reynolds, C. E., Helle, G., and Schleser, G. H.: Wood cellulose preparation methods and mass spectrometric analyses of $\delta^{13} \mathrm{C}, \delta^{18} \mathrm{O}$, and nonexchangable $\delta^{2} \mathrm{H}$ values in cellulose, sugar, and starch: an interlaboratory comparison, Anal. Chem., 79, 4603-4612, 2007.

Brewer, S., Alleaume, S., Guiot, J., and Nicault, A.: Historical droughts in Mediterranean regions during the last 500 years: a data/model approach, Clim. Past, 3, 355-366, doi:10.5194/cp-3355-2007, 2007.

Briffa, K. R., Jones, P. D., Schweingruber, F. H., and Osborn, T. J.: Influence of volcanic eruptions on Northern Hemisphere summer temperature over the past 600 years, Nature, 393, 450-455, 1998.

Büntgen, U., Frank, D. C., Nievergelt, D., and Esper, J.: Summer temperature variations in the European Alps, A.D. 755-2004, J. Climate, 19, 5606-5623, 2006. 
Büntgen, U., Frank, D., Grudd, H., and Esper, J.: Long-term summer temperature variations in the Pyrenees, Clim. Dynam., 31, 615-631, 2008.

Camuffo, D.: Freezing of the venetian lagoon since the $9^{\text {th }}$ century A.D. in comparision to the climate of western Europe and England, Climatic Change, 10, 43-66, 1987.

Chbouki, N., Stockton, C. W., and Myers, D.: Spatio-temporal patterns of drought in Morocco, Int. J. Climatol., 15, 187-205, 1995.

Christensen, J. H., Hewiston, B., Busuioc, A., Chen, A., Gao, X., Held, I., Jones, R., Kolli, R. K., Kwon, W. T., Laprise, R., Magaña Rueda, B., Mearns, L., Menéndez, C. G., Räisänen, J., Rinke, A., Sarr, A., and Whetton, P.: Regional Climate Projections, in: Climate Change 2007: T he Physical Science Basis, Contribution of Working Group I to the Fourth Assessment Report of the Intergovernmental Panel on Climate Change, edited by: Solomon, S., Qin, D., Manning, M., Chen, Z., Marquis, M., Avery, K. B., Tignor, M., and Miller, H. L., Cambridge University Press, Cambridge, 2007.

Conchon, O.: Quaternary Studies in Corsica, Quatern. Res. 9, 4153, 1978.

Conchon, O.: Quaternary glaciations in Corsica, in: Quaternary glaciations in the Northern Hemisphere, edited by: Solomon, S., Qin, D., Manning, M., Chen, Z., Marquis, M., Avery, K. B., Tignor, M., and Miller, H. L., Quaternary Sci. Rev., 5, 429-432, 1986.

Cook, E. R. and Kairiukstis, L. A. (Eds.): Methods of Dendrochronology, Applications in the Environmental Sciences, Kluwer Academic Publisher, Dordrecht, 1990.

D'Arrigo, R. D. and Jacoby, G. C.: Northern North American treering evidence for regional temperature change after major volcanic events, Climatic Change, 41, 1-15, 1999.

D'Arrigo, R. D. and Cullen, H. M.: A 350-year (AD 1628-1980) reconstruction of Turkish precipitation, Dendrochronologia, 19, 167-177, 2001.

Danis, P. A., Masson-Delmotte, V., Stievenard, M., Guillemin, M. T., Daux, V., Naveau, P., and von Grafenstein, U.: Reconstruction of past precipitation $\delta^{18} \mathrm{O}$ using tree-ring cellulose $\delta^{18} \mathrm{O}$ and $\delta^{13} \mathrm{C}$ : A calibration study near Lac d'Annecy, France, Earth Planet. Sc. Lett., 243, 439-448, 2006.

Dawes, M. A., Hättenschwiler, S., Bebi, P., Hagedorn, F., Handa, I. T., Körner, C., and Rixen, C.: Species-specific tree growth responses to 9 years of $\mathrm{CO}_{2}$ enrichment at the alpine treeline, J. Ecol., 99, 383-394, 2011.

Edwards, T. W. D., Birks, S. J., Luckman, B. H., and MacDonald, G. M.: Climatic and hydrologic variability during the past millennium in the eastern Rocky Mountains and northern Great Plains of western Canada, Quatern. Res., 70, 188-197, 2008.

Esper, J., Frank, D., Büntgen, U., Verstege, A., Luterbacher, J., and Xoplaki, E.: Long-term drought severity variations in Morocco, Geophys. Res. Lett., 34, L17702, doi:10.1029/2007GL030844, 2007.

Etien, N., Daux, V., Masson-Delmotte, V., Stievenard, M., Bernard, V., Durost, S., Guillemin, M. T., Mestre, O., and Pierre, M.: A bi-proxy reconstruction of Fontainebleau (France) growing season temperature from A.D. 1596 to 2000, Clim. Past, 4, 91-106, doi:10.5194/cp-4-91-2008, 2008.
Farquhar, G. D., O'Leary, M. H., and Berry, J. A.: On the relationship between carbon isotope discrimintation and the intercellular carbon dioxide concentration in leaves, Aust. J. Plant Physiol., 9, 121-137, 1982.

Feng, X. and Epstein, S.: Carbon isotopes from trees from arid environments and implications for reconstructing atmospheric $\mathrm{CO}_{2}$ concentrations, Geochim. Cosmochim. Acta, 59, 25992608, 1995.

Fritts, H. C.: Tree Rings and Climate, Academic, London, 1976.

Gagen, M., McCarroll, D., Loader, N. J., Robertson, I., Jakanen, R., and Anchukaitis, K. J.: Exorcising the 'segment length curse': summer temperature reconstruction since AD 1640 using nondeternded stable carbon isotope ratios from pine trees in northern Finland, Holocene, 17, 435-446, 2007.

Gao, X. and Giorgi, F.: Increased aridity in the Mediterranean region under greenhouse gas forcing estimated from high resolution simulations with a regional climate model, Global Planet. Change, 62, 195-209, 2008.

Glueck, M. F. and Stockton, C. W.: Reconstruction of the North Atlantic Oscillation, 1429-1983, Int. J. Climatol., 21, 1453-1465, 2001.

Griggs, C., Degaetano, A., Kuniholm, P., and Newton, M.: A regional high-frequency reconstruction of May-June precipitation in the north Aegean from oak tree rings, AD 1089-1989, Int. J. Climatol., 27, 1075-1089, 2007.

Guiot, J., Tessier, L., Serre-Bachet, F., Giubal, F., Gadbin, C., and Till, C.: Annual temperature changes reconstructed in W. Europe and N.W. Africa back to A.D. 1100, Ann. Geophys., Special Issue, 85, 1988.

Hättenschwiler, S., Miglietta, F., Raschi, A., and Körner, C.: Thirty years of in situ tree growth under elevated $\mathrm{CO}_{2}$ : a model for future forest responses?, Global Change Biol., 3, 365-375, 1997.

Hilasvuori, E., Berninger, F., Sonninen, E., Tuomenvirta, H., and Jungner, H.: Stability of climate signal in carbon and oxygen isotope records and ring width from Scots pine (Pinus sylvestris L.) in Finland, J. Quaternary Sci., 24, 469-480, 2009.

Hulme, M. and Jones, P. D.: Global climate change in the instrumental period. Environ. Poll., 83, 23-36, 1994.

IPCC: The Physical Science Basis. Contribution of Working Group I to the Fourth Assessment Report of the Intergovernmental Panel on Climate Change, Cambridge University Press, Cambridge, UK and New York, NY, USA, 2007.

Körner, C.: Plant $\mathrm{CO}_{2}$ responses: an issue of definition, time and resource supply, New Phytol., 172, 393-411, 2006.

Kress, A., Saurer, M., Siegwolf, R. T. W., Frank, D. C., Esper, J., and Bugmann, H.: A 350 year drought reconstruction from Alpine tree ring stable isotopes, Global Biogeochem. Cy., 24, GB2011, doi:10.1029/2009GB003613, 2010.

Kuhlemann, J., Frisch, W., Székely, B., Dunkl, I., Danišík, M., and Krumrei, I.: Würmian maximum glaciation in Corsica, Aust. J. Earth Sci., 97, 68-81, 2005.

Kuhlemann, J., Rohling, E. J., Krumrei, I., Kobik, P., Ivy-Ochs, S., and Kucera, M.: Regional synthesis of Mediterranean atmospheric circulation during the Last Glacial Maximum, Science, 321, 1338-1340, 2008.

Kuhlemann, J., Frisch, W., and Meschede, M.: Korsika, Geologie, Natur und Landschaft, Exkursionen, in: Sammlung Geologischer Führer, Band 99, Gebrüder Borntraeger, Berlin, Stuttgart, 2009. 
Kürschner, K.: Leaf stomata as biosensors of paleoatmospheric $\mathrm{CO}_{2}$-levels, LPP Contributions Series No. 5, LPP Foundation, Utrecht, 143 pp., 1996.

Kürschner, K. and Popik, M. G.: Zur Analyse von Hölzern, Mitteilungen zur Chemie, Physik, Biologie und Technik des Holzes, 16, 1-11, 1962.

Landsberg, H. E.: Variable solar emissions, the 'Maunder Minimum' and climatic temperature fluctuations, Arch. Meteorol. Geophys. Bioclimatol. B, 28, 181-191, 1980.

Lipp, J., Trimborn, P., Fritz, P., Moser, H., Becker, B., and Frenzel, B.: Stable isotopes in tree ring cellulose and climatic change, Tellus B, 43, 322-330, 1991.

Loader, N.J., McCarroll, D., Gagen, M., Robertson, I., and Jalkanen, R.: Extracting climatic information from stable isotopes in tree rings, in: Stable isotopes as indicators of ecological change, edited by: Dawson, T. E. and Siegwolf, R. T. W., Elsevier, 27-48, 2007.

Luterbacher, J., Dietrich, D., Xoplaki, E., Grosjean, M., and Wanner, H.: European seasonal and annual temperature variability, trends and extremes since 1500, Science, 303, 1499-1503, 2004.

Masson-Delmotte, V., Raffalli-Delerce, G. P., Danis, A., Yiou, P., Stievenard, M., Guibal, F., Mestre, O., Bernard, V., Goosse, H., Hoffmann, G., and Jouzel, J.: Changes in European precipitation seasonality and in drought frequencies revealed ba a fourcentury-long tree-ring isotopic record from Brittany, western France, Clim. Dynam., 24, 57-69, 2005.

McCarroll, D. and Loader, N. J.: Stable isotopes in tree rings, Quaternary Sci. Rev., 23, 771-801, 2004.

McCarroll, D., Gagen, M. H., Loader, N. J., Robertson, I., Anchukaitis, K. J., Los, S., Young, G. H. F., Jalkanen, R., Kirchhefer, A., and Waterhouse, J. S.: Correction of tree ring stable carbon isotope chronologies for changes in the carbon dioxide content of the atmosphere, Geochim. Cosmochim. Acta, 73, 15391547, 2009.

Météo-France: Temperature and Precipitation Records of MétéoFrance Weather Stations, http://france.meteofrance.com/ (last access: October 2012), 2010.

Mitchell, T. D., Hulme, M., and New, M.: Climate data for political areas, Area, 34, 109-112, 2002.

Nicault, A., Alleaume, S., Brewer, S., Carrer, M., Nola, P., and Guiot, J.: Mediterranean drought fluctuation during the last 500 years based on tree-ring data, Clim. Dynam., 31, 227-245, 2008.

Pauling, A., Luterbacher, J., Carlo, C., and Wanner, H.: Five hundred years of gridded high-resolution precipitation reconstructions over Europe and the connection to large-scale circulation, Clim. Dynam., 26, 347-405, 2006.

Pimont, F., Prodon, R., and Rigolot, E.: Comparison of postfire mortality in endemic Corsican black pine (Pinus nigra ssp. laricio) and its direct competitor (Pinus pinaster), Ann. Forest Sci., 68, 425-432, 2011.

Popa, I. and Kern, Z.: Long-term summer temperature reconstruction inferred from tree-ring records from the Eastern Carpathians, Clim. Dynam., 32, 1107-1117, 2009.

Reille, M., Gamisans, J., de Beaulieu, J.-L., and Andrieu, V.: The late-glacial at Lac de Creno (Corsica, France): a key site in the western Mediterranean basin, New Phytol., 135, 547-559, 1997.

Richardson, D. M. (Ed.): Ecology and Biogeography of Pinus, Cambridge University Press, Campbridge, p. 535, 1998.
Rinn: TSAP-Win Time Series Analysis and Presentation for Dendrochronology and Related Applications, User Reference, Heidelberg, 2008.

Rossi, P. and Cocherie, A.: Genesis of a Variscan batholith: field, petrological and mineralogical evidence from the CorsicaSardinia batholith, in: The European Geotraverse, Part 7, edited by: Freeman, R., Huch, M., and Mueller, S., Tectonophysics, 195, 319-346, 1991.

Sachs, J. P., Sachse, D., Smittenberg, R. H., Zhang, Z., Battisti, D. S., and Golubic, S.: Southward movement of he Pacific intertropical convergence zone AD 1400-1850, Nat. Geosci., 2, 519-525, doi:10.1038/ngeo554, 2009.

Serre-Bachet, F.: Middle ages temperature reconstructions in Europe, a focus on northeastern Italy, Climatic Change, 26, 213224, 1994.

Serre-Bachet, F. and Guiot, J.: Summer temperature changes from tree-rings in the Mediterranean area during the last 800 years, edited by: Berger, W. and Labeyrie, L., Reidel, Dordrecht, 8998, 1987.

Sho, K., Takahashi, H. A., Miyai, H., Ikebuchi, S., and Nakamura, T.: Tree-ring width and stable carbon isotope composition of japanese cypress in the lake Biwa area, central Japan, and their hydrologic and climatic implications, IAWA J., 30, 395-406, 2009.

Szymczak, S., Joachimski, M. M., Bräuning, A., Hetzer, T., and Kuhlemann, J.: Comparison of whole wood and cellulose carbon and oxygen isotope series from Pinus nigra ssp. laricio (Corsica/France), Dendrochronologia, 29, 219-226, 2011.

Szymczak, S., Joachimski, M. M., Bräuning, A., Hetzer, T., and Kuhlemann, J.: Are pooled tree ring $\delta^{13} \mathrm{C}$ and $\delta^{18} \mathrm{O}$ series reliable climate archives? - a case study of Pinus nigra ssp. laricio (Corsica/France), Chem. Geol., 308-309, 40-49, 2012.

Till, C. and Guiot, J.: Reconstruction of precipitation in Morocco since $1100 \mathrm{AD}$ based on Cedrus atlantica tree-ring widths, Quatern. Res., 33, 337-351, 1990.

Touchan, R., Meko, D., and Highes, M. K.: A 396-year reconstruction of precipitation in southern Jordan, J. Am. Water Resour. Assoc., 35, 49-59, 1999.

Touchan, R., Garfin, G. M., Meko, D. M., Funkhouser, G., Erkan, N., Hughes, M. K., and Wallin, B. S.: Preliminary reconstructions of spring precipitation in southwestern turkey from treering width, Int. J. Climatol., 23, 157-171, 2003.

Touchan, R., Funkhouser, G., Hughes, M. K., and Erkan, N.: Standardized precipitation index reconstructed from turkish tree-ring widths, Climatic Change, 72, 339-353, 2005a.

Touchan, R., Xoplaki, E., Funkhouser, G., Luterbacher, J., Hughes, M. K., Erkan, N., Akkemik, Ü., and Stephan, J.: Reconstructions of spring/summer precipitation for the Eastern Mediterranean from tree-ring widths and its connection to large-scale atmospheric circulation, Clim. Dynam., 25, 75-98, 2005b.

Touchan, R., Akkemik, Ü., Hughes, M. K., and Erkan, N.: May-June precipitation reconstruction of southwestern Anatolia, Turkey during the last 900 years from tree rings, Quatern. Res., 68, 196-202, 2007.

Touchan, R., Anchukaitis, K. J., Meko, D. M., Attalah, S., Baisan, C., and Aloui, A.: Long-term context for recent drought in northwestern Africa, Geophys. Res. Lett., 35, L13705, doi:10.1029/2008GL034264, 2008a. 
Touchan, R., Meko, D. M., and Aloui, A.: Precipitation reconstructions for Northwestern Tunisia from tree rings, J. Arid Environ., 72, 1887-1896, 2008b.

Touchan, R., Anchukaitis, K. J., Meko, D., Sabir, M., Attalah, S., and Aloui, A.: Spatiotemporal drought variability in northwestern Africa over the last nine centuries, Clim. Dynam., 37, 237252, doi:10.1007/s00382-010-0804-4, 2011.

Treydte, K. S., Schleser, G. H., Schweingruber, F. H., and Winiger, M.: The climatic significance of $\delta^{13} \mathrm{C}$ in subalpine spruces (Lötschental, Swiss Alps), Tellus B, 53, 593-611, 2001.

Treydte, K. S., Frank, D. C., Saurer, M., Helle, G., Schleser, G., and Esper, J.: Impact of climate and $\mathrm{CO}_{2}$ on a millennium-long tree-ring carbon isotope record, Geochm. Cosmochim. Acta, 73, 4635-4647, 2009.

Waterhouse, J. S., Swistur, V. R., Barker, A. C., Carter, A. H. C., Hemming, D. L., Loader, N. J., and Robertson, I.: Northern European trees show a progressively diminishing response to increasing atmospheric carbon dioxide concentrations, Quaternary Sci. Rev., 23, 803-810, 2004.
Young, G. H. F., McCarroll, D., Loader, N. J., and Kirchhefer, A. J.: A 500-year record of summer near-ground solar radiation from tree-ring stable carbon isotopes, Holocene, 20, 315-324, 2010.

Young, G. H. F., Demmler, J. C., Gunnarson, B. E., Kirchhefer, A. J., Loader, N. J., and McCarroll, D.: Age trends in tree ring growth and isotopic archives: A case study of Pinus sylvestris L. from northwestern Norway, Global Biogeochem. Cy., 25, GB2020, doi:10.1029/2010GB003913, 2011.

Young, G. H. F., Bale, R. J., Loader, N. J., McCarroll, D., Nayling, N., and Vousden, N.: Central England temperature since AD 1850: the potential of stable carbon isotopes in British oak trees to reconstruct past summer temperatures, J. Quaternary Sci., 27, 606-614, doi:10.1002/jqs.2554, 2012. 